OPEN ACCESS

Edited by:

Djuro Kosanovic,

I.M. Sechenov First Moscow State

Medical University, Russia

Reviewed by:

Oleg Pak,

University of Giessen, Germany

Yehuda Julyus Shoenfeld,

Sheba Medical Center, Israel

${ }^{*}$ Correspondence:

Yanjiang Xing

xingyanjiang@ibms.pumc.edu.cn

Jing Wang

wangjing@ibms.pumc.edu.cn

Specialty section:

This article was submitted to

Hypertension,

a section of the journa

Frontiers in Cardiovascular Medicine

Received: 13 March 2021

Accepted: 12 August 2021

Published: 21 September 2021

Citation:

Shu T, Xing Y and Wang J (2021)

Autoimmunity in Pulmonary Arterial

Hypertension: Evidence for Local

Immunoglobulin Production.

Front. Cardiovasc. Med. 8:680109.

doi: 10.3389/fcrm.2021.680109

\section{Autoimmunity in Pulmonary Arterial Hypertension: Evidence for Local Immunoglobulin Production}

\author{
Ting Shu ${ }^{1}$, Yanjiang Xing ${ }^{2 *}$ and Jing Wang ${ }^{1 *}$ \\ ${ }^{1}$ State Key Laboratory of Medical Molecular Biology, Department of Pathophysiology, Institute of Basic Medical Sciences, \\ Chinese Academy of Medical Sciences, Peking Union Medical College, Beijing, China, ${ }^{2}$ State Key Laboratory of Medical \\ Molecular Biology, Department of Physiology, Institute of Basic Medical Sciences, Chinese Academy of Medical Sciences, \\ Peking Union Medical College, Beijing, China
}

Pulmonary arterial hypertension (PAH) is a progressive life-threatening disease. The notion that autoimmunity is associated with $\mathrm{PAH}$ is widely recognized by the observations that patients with connective tissue diseases or virus infections are more susceptible to $\mathrm{PAH}$. However, growing evidence supports that the patients with idiopathic PAH (IPAH) with no autoimmune diseases also have auto-antibodies. Anti-inflammatory therapy shows less help in decreasing auto-antibodies, therefore, elucidating the process of immunoglobulin production is in great need. Maladaptive immune response in lung tissues is considered implicating in the local auto-antibodies production in patients with IPAH. In this review, we will discuss the specific cell types involved in the lung in situ immune response, the potential auto-antigens, and the contribution of local immunoglobulin production in PAH development, providing a theoretical basis for drug development and precise treatment in patients with $\mathrm{PAH}$.

Keywords: pulmonary arterial hypertension, adaptive response, auto-antibody, auto-antigen, immunoglobulins

\section{INTRODUCTION}

Pulmonary arterial hypertension (PAH) is characterized by pulmonary vascular remodeling in pathology, leading to the elevation of mean pulmonary arterial pressure. Pulmonary vascular remodeling is seen as a result of perivascular inflammatory cells infiltration and pulmonary arterial wall dysfunctions $(1,2)$. The inflammatory cells infiltration is considered as both the cause and the consequence of pulmonary vascular remodeling. Innate response and adaptive response are found in the lung tissues of clinic PAH and experimental $\mathrm{PH}(1-4)$. The innate response is participated by macrophages/monocytes (5), mast cells (6), neutrophils (7), etc. These cells are recruited from peripheral blood and infiltrated around pulmonary vessels. Macrophages, especially interstitial macrophages, function by releasing cytokines or chemokines, such as IL-6, TNF $\alpha$, and CCL2. TNF $\alpha$ suppressed BMPRII expression in pulmonary arterial endothelial cells (PAECs) and pulmonary arterial smooth muscle cells (PASMCs) (8). IL-6 promotes PASMC proliferation and activates fibroblasts (9). CCL2 will recruit more inflammatory cells into the lung tissues and promotes crosstalk between macrophages and PASMCs (10). Mast cells and neutrophils belonged to the granulocytes, which will degranulate once activated. Granule content, such as myeloperoxidase (MPO) in neutrophils or protease in mast cells, contributes to pulmonary vascular remodeling $(6,11)$. Antigen-presenting cells (APCs) will also be attracted by chemokines in the early stage (12). The identification of dendritic cells (DCs) revealed the link between the innate response and 
adaptive response (13). Adaptive immunity is participated by $\mathrm{T}$ cells and $\mathrm{B}$ cells. APCs mediate $\mathrm{T}$ cell differentiating into subtypes, such as helper $\mathrm{T}$ cells or cytotoxic $\mathrm{T}$ lymphocytes. Furthermore, $\mathrm{T}$ cells interact with $\mathrm{B}$ cells and promote B-cell maturation. Moreover, auto-antibodies with atopy are produced, even in the patients with idiopathic PAH (IPAH) without a diagnosis of autoimmune diseases (14). This research suggests the local adaptive response in IPAH lung. The innate response has been recognized for decades (15); however, the role of adaptive response is reported in recent years. This review aimed to update the contribution of adaptive immune cells in patients with experimental PH and IPAH, summarize the potential target auto-antigens, discuss the types and functions of locally produced immunoglobulins, and provide promising therapeutic targets for clinic treatment.

\section{IMMUNE CELLS INVOLVED IN ADAPTIVE IMMUNITY}

In 2005, Dr. Nicolls had hypothesized the in situ adaptive immune response and immunoglobulin generation in the IPAH lung tissues without direct evidence (16). Decades later, the key components involved in this hypothesis have been reported. The concept of local adaptive response is that pulmonary vascular injury leads to auto-antigens exposure, which are phagocytized by DCs and then presented to T cells; $\mathrm{T}$ cells are activated and interact with B cells, leading to B-cell antibody class-switching recombination and immunoglobulins production $(1,16)$. In this process, DCs, T cells, and B cells play essential roles.

\section{Dendritic Cells}

The infiltration of DCs is observed in both IPAH and experimental pulmonary hypertension (PH) (17). Infiltrated DCs showed different gene expression signatures among the different species, which have been discussed in a previous review (18). In $\mathrm{IPAH}$, perivascular DCs exhibit CD1a ${ }^{-}$, for rat $\mathrm{PH}$, the signature is $\mathrm{OX}-62^{+}(17)$. This signature indicated the perivascular DCs is immature, possessing the ability for antigens presentation (17). Immature DCs are also considered as steady state and can be classified as conventional DCs (cDCs) and plasmacytoid DCs (pDCs) $(13,18)$. cDCs raise more attention as they show a higher frequency compared with pDCs (18). cDCs have two subsets, among which the conventional DCs subtype 2 (cDC2s) is the major population in both blood and lung tissues. The $\mathrm{cDC} 2 \mathrm{~s}$ are highly expressed MHCII, while cDC1s are superior in MHCI expression (19). The MHCI/II expressed in cDCs suggests its power in presenting the antigens. The previous studies show that in the patients with IPAH, cDCs are decreased in the blood (20) but increased in the lung tissues (21). This observation can be explained by the infiltration and retention of DCs in lung tissue. CCR7 is crucial in DCs recruitment to lymph-vessel $(22,23)$. CCR7 deficiency resulted in the failure of DCs homing, eventually being accumulated in the lung tissue (12). The role of $\mathrm{cDCs}$ is predicted by Tnfaip3/A20 deficient mice in which cDCs are activated through NF- $\mathrm{B}$ signaling (24). Activated cDCs increased perivascular inflammation and subsequently aggravated $\mathrm{PH}$ in mice (24), suggesting its detrimental role in $\mathrm{PAH} / \mathrm{PH}$ development. The infiltration of pDCs in IPAH lung tissues was first reported in 2018 (21). As a lower frequency subset, pDCs were captured by single-cell sequencing and identification in lung tissues of the patients with IPAH. Increased pDCs number was confirmed by flow cytometry and its location was revealed by staining. Although we have observed pDCs accumulation around pulmonary vessels in IPAH (21), it is hard to clarify its function as a lack of experimental evidence. Based on the function of pDCs in other tissues (25), we predicted pDCs is crucial in antivirus as it is capable in expressing interferon gene signature (such as IFN- $\gamma$, CXCL4, and CXCL10) $(21,25)$. These cytokines and chemokines suggest their unique pattern in cross-linking with $\mathrm{T}$ cells and leukocytes activation (26).

\section{T Cells}

Naïve $\mathrm{T}$ cells that received antigen presentation by DCs will be activated and differentiate into $\mathrm{CD} 4^{+} \mathrm{T}$ cells or $\mathrm{CD} 8^{+} \mathrm{T}$ cells. Different DCs subtypes have the variant capacity in stimulating T-cells differentiation. cDC2s are more powerful in promoting $\mathrm{CD}^{+} \mathrm{T}$ cells, while $\mathrm{cDC} 1 \mathrm{~s}$ are superior in activating $\mathrm{CD} 8^{+}$ $T$ cells $(19,27)$. The microenvironments surrounded the crosspresentation site between DCs and naïve $\mathrm{T}$ cells decide the differentiation destination of $\mathrm{T}$ cells. Conventionally, $\mathrm{CD} 4^{+} \mathrm{T}$ cells are divided into T helper 1 (Th1), Th2, Th17, and regulatory T cells (Treg) (28). Th1 polarization is triggered by IFN- $\gamma$, IL12 , and IL-18, and suppressed by IL- 4 and TGF- $\beta$ (29). Th1 cells release Th1 cytokines, such as IL-12, IFN- $\gamma$, and TNF- $\alpha$, however, their contributions in clinic $\mathrm{PAH}$ and experimental $\mathrm{PH}$ are not reported clearly. Th2 polarization is induced by IL- 4 and suppressed by IFN- $\gamma(29,30)$. Th2 cytokines include IL-4, IL-5, and IL-13 (30). Th2 cells infiltration and Th2 cytokines production are observed in the lung tissues of patients with IPAH and experimental subjects $(31,32)$. The previous studies have demonstrated that Th2 promotes PASMCs proliferation through IL-4 and IL-13 releasing $(31,32)$. Moreover, Th2 cells and Th2 cytokines (IL- 4 and IL-5) are capable of the activation of $\mathrm{B}$ cells, and it facilitates immunoglobulin class-switching in B cells (33-35). Th17 polarization is stimulated by IL-1 $\beta$, IL-6, IL-23, and TGF- $\beta$. Th17 cytokines are featured as IL17 and GM-CSF. Th17 cells infiltration and IL-17 elevation are observed in the clinic and experimental PAH/PH $(36,37)$. Over-expressing IL-17 or blocking IL-17 in mice regulates the PH development through directly affected PAECs and PASMCs function (37). T cells that received IL-2, IL-10, and TGF- $\beta$ stimulation will be polarized into Treg (28). Treg is well-known as a suppressor for the inflammatory cells in many diseases (38). In PAH/PH development, Treg suppresses vascular inflammation and alleviates $\mathrm{PH}$ development. These functions are observed as rats that lack Treg are more susceptible to PH (39-41), and reconstituting Treg to hypoxic mice protected against $\mathrm{PH}$ development (42). In patients with IPAH, circulating Treg portion increased and exhibited aberrant subtypes compared with control subjects (43-45), whether these changes are seen in lung tissues need further exploration. $\mathrm{CD} 8^{+} \mathrm{T}$ cells are activated by cDC1s $(19,27)$. In patients with IPAH, circulating $\mathrm{CD} 8^{+}$ $\mathrm{T}$ cells portion decreased compared with control subjects (46), 
but increased in PAH lung tissues, especially in obstructed sites $(46,47)$. Single-cell sequencing identified increased CD ${ }^{+} \mathrm{T}$ cells proportion in lung tissues of patients with IPAH (21), however, its role in PAH development needs more experimental exploration. $\mathrm{T}$ cells that expressed T-cell receptor (TCR) and received DCs cross-presentation (as described above) belong to the $\alpha \beta \mathrm{T}$ cells. The other subset of T cells without TCR are named as $\gamma \delta \mathrm{T}$-cells (48). The presence of $\gamma \delta$ T-cells is first identified in 2018 (21). Dr. Marsh showed increased $\gamma \delta \mathrm{T}$-cells proportion in the lung tissues of patients with IPAH (21). The $\gamma \delta \mathrm{T}$-cells response is independent of antigen presentation by DCs, therefore $\gamma \delta \mathrm{T}$-cells belong to the innate immune (48).

\section{B Cells}

The $\mathrm{B}$ cells are the core components in adaptive response and immunoglobulins production. The infiltration of B cells in lung tissues is seen in the patients with IPAH and experimental $\mathrm{PH}$ subjects $(49,50)$. Deletion of B cells protected rats against MCTinduced $\mathrm{PH}$ development (50). In adaptive response, B cells are activated by cross-linking with $\mathrm{CD}^{+} \mathrm{T}$ cells. The activated $\mathrm{B}$ cells are named plasma cells (51), as they possess the ability to produce immunoglobulins. Plasma cells are detected in blood and lung tissues of patients with IPAH $(51,52)$, supporting the notion of auto-antibody production in the patients with IPAH. Immunoglobulin production in B cells is a complicated process, as B cells will experience the VDJ recombination and the antibody class-switching recombination. Conventionally, naïve $\mathrm{B}$ cells are producing IgM. Once being activated, B cells switch the heavy chain constant region from IgM to IgG, IgA, or IgE, without changing the antigen-binding site (53). Cytokines released by Th play crucial roles in mediating class-switching. IL-4 released by Th2 prompts the B cells to switch into IgG and IgE isotype (54). IFN- $\gamma$ released by Th1 promotes IgG class-switching. TGF- $\beta$ and IL- 5 participate in IgA isotype classswitching $(26,34)$. Although T-cell independent pathways are also involved in B-cell class-switching, the present focus of $\mathrm{T}$ cells could be expanded into T cell-mediated B-cell interactions. Dr. Blum analyzed the circulating B cells in the blood of the patients with IPAH through single-cell sequencing and found that these cells are increased in number and changed in transcript signature (51). The observation of mature antibody production suggested the class-switching occurred in plasmablasts in patients with IPAH. In this process, different immunoglobulin isotypes might be produced (51). Another study found B-cell activation in circulating blood, indicated by increased Bruton's tyrosine kinase (BTK) expression in B cells from the patients with IPAH, suggesting the enhanced BCR signaling in these patients (55).

\section{Tertiary Lymphoid Organs}

Tertiary lymphoid organs are structures observed in the lung tissues of clinic IPAH and experimental PH $(49,52)$. TLOs are similar to lymph nodes, locating around pulmonary vessels. The plasma cells constituted the core of TLOs structure with Th surrounded and DCs infiltrated in the border (49). The presence of TLOs suggested the immune cells as discussed above are not scattered in the lung tissue but have a close histological relationship instead. As described above, the formation of
TLOs is the result of cells infiltration and retention. First, downregulation of CCR7 in PH subject block DCs homing. Then, activated DCs release cytokines that attract T cells and $\mathrm{B}$ cells, such as CCL19/21, lymphotoxin $\beta$ receptor (LTBR), and CXCL13 $(49,52)$. Block DCs homing through CCR7 antagonism enlarged the size of TLOs in MCT-induced $\mathrm{PH}$ rats, while block B-cells infiltration through LTBR blockade decreased the size of TLOs (49). Experimental reduction of the TLOs also decreased the production of immunoglobulins in rat $\mathrm{PH}$. This evidence suggests that the TLOs facilitate the cell-cell interaction during the adaptive response in the $\mathrm{PH}$ lung and are crucial for auto-antibody production and $\mathrm{PH}$ development (as shown in Figure 1).

\section{AUTO-ANTIGEN EXPOSURE}

Antigens mediate the pathogen recognition process and receive antibody binding in adaptive response. Therefore, identifying the local auto-antigens is crucial in IPAH and experimental PH. Vascular injury is considered the initiator of adaptive response in autoimmunity-involved vascular diseases $(56,57)$. Similarly, the pulmonary vascular lesion is considered as the repository of the auto-antigens in clinic IPAH or experimental PH. Experimentally stabilizing pulmonary vessels through Salubrinal decreased the TLOs formation and auto-antibodies production in MCTinduced rat PH (49). Among the cells constructed in the vessels, pulmonary endothelial cells and fibroblasts are the sources of auto-antigens in PAH. The identification of target antigens was revealed through the proteome approach, and the potential target antigen is listed in Table $\mathbf{1 .}$

\section{Auto-Antigens in Fibroblasts}

Approximately $40 \%$ of the patients with IPAH carrying antifibroblast antibodies (AFAs) suggest the pool of antigens exposed in fibroblast (58). Dr. Terrier identified 16 potential target antigens through MALDI-TOF MS in sera of human IPAH (58). These target antigens are mainly involved in the cytoskeletal organization (vimentin, calumenin, and phosphatidylinositol 3 kinase), cell contraction (Tropomyosin 1), and oxidative stress (heat shock protein (HSP) 27, HSP 70, and glucose-6-phosphate dehydrogenase) (58). Similarly, the auto-antigens expressed in the fibroblasts were observed in experimental PH (49). In both hypoxia-induced $\mathrm{PH}$ rats and MCT-induced $\mathrm{PH}$ rats, autoantibody was specifically combined with pulmonary adventitial fibroblasts $(49,61)$, suggesting the auto-antigens exposure in fibroblasts.

\section{Auto-Antigens in Endothelial Cells}

In patients with IPAH, serum IgG antibody showed higher intensity in binding with endothelial cells extracts, suggesting the potential target antigen exposed in pulmonary endothelial cells (62). The prevalence of anti-endothelial cell antibodies (AECAs) in the patients with IPAH was $62.1 \%$ in IgG isotype and $44.8 \%$ in IgM isotype (14), however, in small populations. Similarly, by proteomic approach, lamin $\mathrm{A} / \mathrm{C}$ and tubulin $\beta$-chain were identified as the target of AECAs (59). 


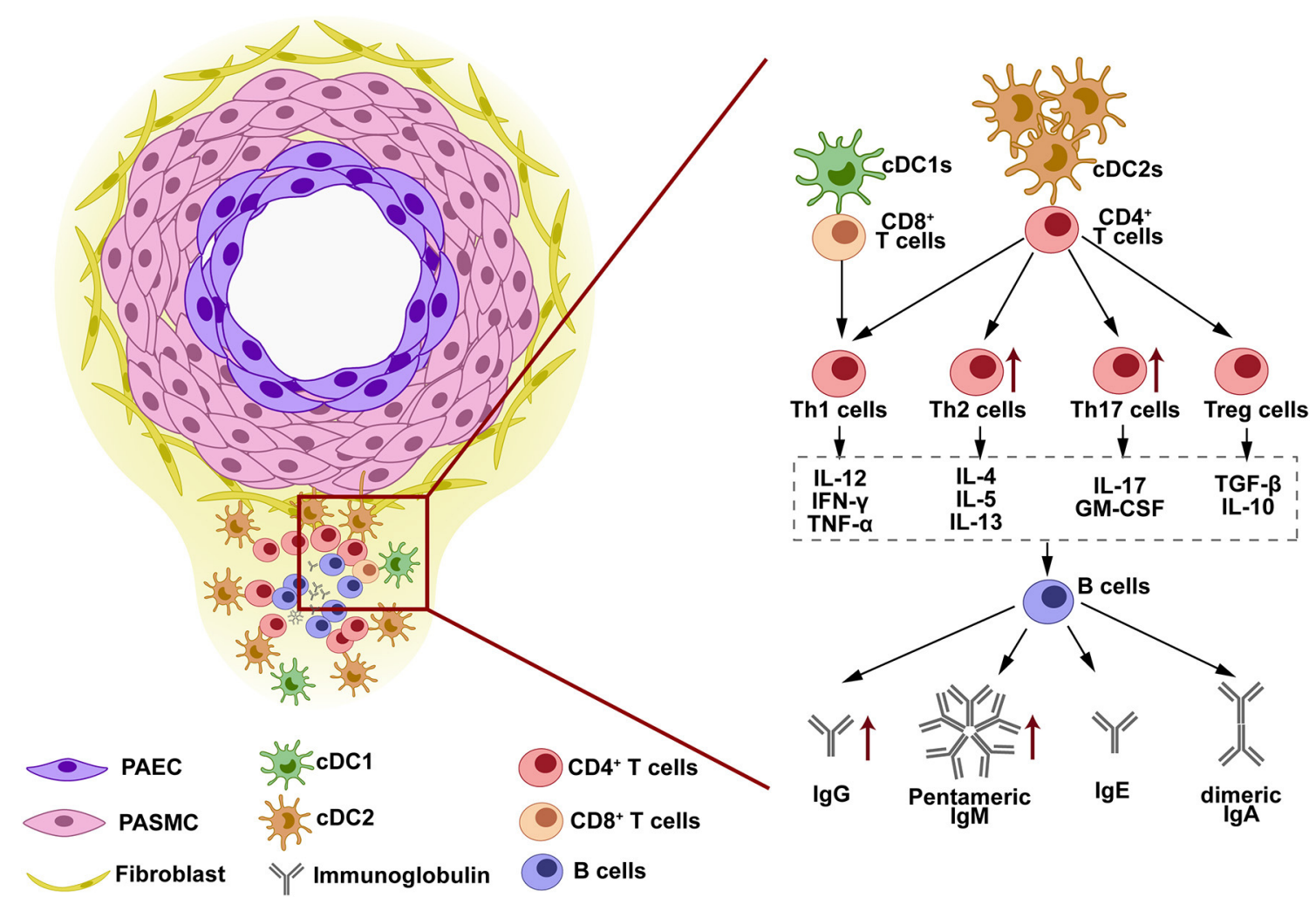

FIGURE 1 | The structure and immune response in tertiary lymphoid organs (TLOs). TLOs are found around the pulmonary vascular lesion in the lung tissues of clinic pulmonary arterial hypertension (PAH) and experimental pulmonary hypertension (PH). The lymphoid structure of TLOs is constituted by dendritic cells (DCs) at the border, B cells and immunoglobulins at the core, and T cells at the interlayer. This structure facilitates the cell-cell interaction in TLOs. DCs are located in the outer layer of TLOs, closed to the remodeled vessels. Antigens exposed by vessels are phagocytized by DCs and presented to T cells. T cells are activated and differentiated into various subtypes when cross-presenting with DCs. The cytokines released by different T-cell subtypes determine the antibody class-switching destination of B cells when T-B cell interaction occurs. IgG, IgM, IgE, and IgA are released by B cells and can be detected in the lung tissues, serum, and BALF of PAH/PH subjects.

TABLE 1 | Target auto-antigens identified in vessel cells from the patients with idiopathic PAH (IPAH).

\begin{tabular}{lll}
\hline Target cell & Auto-antigens & Mainly functions \\
\hline Fibroblasts (58) & $\begin{array}{l}\text { Vimentin, calumenin, } \\
\text { phosphatidylinositol 3- } \\
\text { kinase } \\
\text { Tropomyosin 1 }\end{array}$ & $\begin{array}{l}\text { Cytoskeletal organization, } \\
\text { cell contraction, oxidative } \\
\text { stress. }\end{array}$ \\
& $\begin{array}{l}\text { HSP 27, HSP 70, } \\
\text { glucose-6- } \\
\text { phosphate dehydrogenase }\end{array}$ & \\
& $\begin{array}{l}\text { Lamin AVC, tubulin } \\
\beta \text {-chain }\end{array}$ & $\begin{array}{l}\text { Nuclear membrane, } \\
\text { microtubules. }\end{array}$ \\
Endothelial cells & Stress-induced & Vascular contraction. \\
(59) & $\alpha$ phosphoprotein 1, & \\
Smooth muscle & \\
cells (60) & $\alpha$-enolase & \\
\end{tabular}

\section{Auto-Antigens in Smooth Muscle Cells}

Dr. Bussone reported that the antigens exposed in vascular smooth muscle cells also attract auto-antibodies binding (60). They reported two targets identified through the proteomic approach, which are stress-induced phosphoprotein 1 and $\alpha$ enolase (60). The detection rate of anti-smooth muscle cells antibody to stress-induced phosphoprotein 1 is $24 \%$ in the patients with IPAH (60).

\section{AUTO-ANTIBODIES PRODUCTION}

In $\mathrm{PAH} / \mathrm{PH}$ lung tissues, B-cell infiltration and activation facilitate the local auto-antibodies production. Immunoglobulins contain Fab fragment and Fc fragment, which are combined with antigens and $\mathrm{Fc}$ receptors, respectively. The auto-antigens exposed by vascular cells have been discussed above. The Fc receptors vary with the $\mathrm{Fc}$ fragment embedded in different immunoglobulin isotypes. As the $\mathrm{Fc}$ receptors are expressed by different effector cells, the injury caused by immunoglobulins varies with the specific effector cells (Table 2).

\section{IgG Isotype}

IgG isotype is the preponderant population in immunoglobulins. Most auto-antibodies observed in clinic IPAH (such as AFAs and AECAs) are $\operatorname{IgG}$ isotypes $(58,62)$. In MCT-induced rat $\mathrm{PH}$, auto-antibody in IgG isotype also showed elevation 
TABLE 2 | The function of auto-antibodies in PAH.

\begin{tabular}{|c|c|c|c|c|c|}
\hline Isotype & Present & Fab fragment targets & Roles & Fc receptors & Effector cells \\
\hline $\lg G$ & $\begin{array}{l}\text { Blood of IPAH } \\
\text { patients (58-60), } \\
\text { experimental PH } \\
\text { subjects }(49,61)\end{array}$ & $\begin{array}{l}\text { Fibroblasts, smooth } \\
\text { smooth muscle cells } \\
\text { and endothelial cells } \\
(58-60)\end{array}$ & $\begin{array}{l}\text { Induce pro-inflammatory } \\
\text { cytokines release in fibroblasts } \\
\text { and endothelial cells }(49,63,64) \text {, } \\
\text { Change phenotypes in } \\
\text { fibroblasts (65), Induce apoptosis } \\
\text { in endothelial cells (66), } \\
\text { activate complement system (61) }\end{array}$ & $\begin{array}{l}F_{c} \gamma R I, F_{c} \gamma R \| l \\
F_{c} \gamma R I I I\end{array}$ & $\begin{array}{l}\text { Monocytes, } \\
\text { macrophages, } \\
\text { dendritic cells, NK } \\
\text { cells }(67,68)\end{array}$ \\
\hline $\lg M$ & $\begin{array}{l}\text { Blood of IPAH } \\
\text { patients (14), } \\
\text { experimental PH } \\
\text { subjects (61) }\end{array}$ & Endothelial cells (14) & $\begin{array}{l}\text { Activate complement system } \\
(61), \text { immune homeostasis } \\
(69,70)\end{array}$ & $\mathrm{FC}_{\mathrm{C}} \mathrm{R}$ & $\begin{array}{l}\text { B cells, T cells, NK } \\
\text { cells }(71)\end{array}$ \\
\hline $\lg \mathrm{E}$ & $\begin{array}{l}\text { BALF of experimental } \\
\text { PH subjects (32) }\end{array}$ & Unclear & Attract effector cells & $F_{c \varepsilon R l}$ & Mast cells (72) \\
\hline $\lg A$ & $\begin{array}{l}\text { Circulating } \\
\text { plasmablasts of IPAH } \\
\text { patients }(51,73)\end{array}$ & Unclear & Attract effector cells & $\mathrm{F}_{\mathrm{C} \alpha \mathrm{RI}}$ & Neutrophils (74) \\
\hline
\end{tabular}

(49). Dr. Colvin collected the autoantibody-containing plasma from MCT-injected rat and transferred into native rats. Rats transferred auto-antibody showed severe PH (49), suggesting the detrimental role of auto-antibody in $\mathrm{PH}$ development. In the cell injury process, on one hand, IgG bind with the target antigens in fibroblasts or endothelial cells through Fab fragment $(58,62)$. These combinations cause phenotype changes in the fibroblasts or endothelial cells. In fibroblasts, AFAs positive IgG stimulation induces profibrotic and proinflammatory chemokines production $(49,63)$, such as CXCL1, CXCL8, IL$1 \beta$, and IL-6. Moreover, fibroblasts change into myofibroblasts phenotypes when received AFAs treatment (65), observed as increased $\alpha$-SMA expression. In endothelial cells, the AECA positive IgG induces ECs apoptosis (66), highly express adhesion molecular and proinflammatory cytokines (64). The phenotype changes in fibroblasts and endothelial cells partially explained perivascular inflammation, endothelial cells dysfunction, vessel stiffness, and muscularization. On the other hand, the Fc fragment in IgG links the effector cells with the antigens. For IgG isotype, its Fc receptors contain Fc $\gamma$ RI (CD64), Fc $\gamma$ RII (CD32), and Fc $\gamma$ RIII (CD16) $(67,68)$. These receptors are mainly expressed in macrophages, monocytes, NK cells, and DCs $(67,68)$. Macrophages and monocytes occupy a large population in the lung tissues, and they play a crucial role in $\mathrm{PAH} / \mathrm{PH}$ development $(5,75)$. The infiltration of macrophages is observed in clinic $\mathrm{PAH}$ and experimental $\mathrm{PH}$. The function of IgG stimulated macrophages is widely recognized as cytokines releasing [such as IL-6 and IL-10 (76)]. The DCs also expressed IgG receptor. DCs mediate Tcell activation upon IgG stimulation (77). IgG receptor Fc $\gamma$ RII also expressed in endothelial cells and smooth muscle cells in the systemic circulation (68), whether it is expressed in pulmonary vascular cells is unknown. Although no direct evidence shows the similar function in IgG auto-antibodies extracted from $\mathrm{PH}$ subject, these research studies suggest that effector cells participate in the IgG auto-antibodies mediated vascular injury.

\section{IgM Isotype}

Autoantibodies in IgM isotype were identified along with IgG isotype in the patients with IPAH (14). The present IgM isotype autoantibodies are mostly AECAs (14). The abnormal IgM is also seen in the experimental $\mathrm{PH}$ mice and rats, and it deposits in the luminal/medial area (61). These observations suggest that the IgM isotype mainly targets intima injury. IgM functions as activating complement system in pathophysiology. Due to its pentameric structure, it shows more powerful than the IgG isotype (78). The complement system is a newly identified participator in perivascular inflammation during $\mathrm{PAH} / \mathrm{PH}$ development $(79,80)$. By proteomic analysis, the activation of complement cascades was discovered as one of the most upregulated signaling pathways in the early stage of $\mathrm{PAH}$ development (61). Similarly, the complement activation was also observed in the hypoxia-induced $\mathrm{PH}$ mice/rats, MCT-induced $\mathrm{PH}$ rats, and Sugen 5416 followed by hypoxia ( $\mathrm{SuHx}$ )-induced $\mathrm{PH}$ rats. Moreover, the level of the complement component is correlated with clinical outcomes of patients with PAH (80). These observations suggest the essential role of the complement system in $\mathrm{PAH} / \mathrm{PH}$ development. A previous study demonstrated that IgM and IgG are critical for the activation of the complement system in hypoxia-induced PH subjects (61). IgM deposition correlated with $\mathrm{C} 4$, suggesting its role in initiating classical and lectin pathways (61). Immunoglobulin deficient mice ( $\mu \mathrm{MT}$ mice) failed to activate complement cascade, subsequently decreased the perivascular inflammation (61). Therefore, the IgM and IgG are the key initiator of complement cascade. The Fc receptor of IgM is named Fc $\mu R$, and it is mostly expressed in lymphocytes (B cells, T cells, and NK cells in human; only B cells in mice) (71). The present knowledge of Fc $\mu \mathrm{R}$ is based on Fcmr-ablated mice. Fcmr-ablated mice exhibited altered the subset of B cells, elevated IgM level, and dysregulated immune responses $(69,70)$, suggesting that $\operatorname{IgM}$ maintains immune homeostasis through $\mathrm{Fc} \mu \mathrm{R}$. A polymeric immunoglobulin receptor (pIgR) is another receptor of $\operatorname{IgM}$ that binds with the $\mathrm{J}$ chain that is carried by polymeric 
immunoglobulins (such as pentameric IgM and dimeric IgA) (81). Th17 and IL-17 upregulated the pIgR expression $(82,83)$, however, the present studies show pIgR mostly expressed in the epithelial cells. Whether pIgR is expressed in leukocytes and whether pIgR participates in IgM mediated pulmonary vascular dysfunction needs further investigation.

\section{IgE Isotype}

IgE elevation is commonly seen in allergic diseases or infectious diseases (84), however, in cardiovascular diseases, $\operatorname{IgE}$ also elevates. Serum IgE level increases in atherosclerosis, left heart failure, and abdominal aortic aneurysm (85-87). A variety of research studies indicate that $\mathrm{IgE}$ contributes to $\mathrm{PAH} / \mathrm{PH}$ development. Ovalbumin (OVA) is an antigen commonly used in mice asthma models (31). OVA-stimulated mice exhibited pulmonary vascular remodeling without right ventricular systolic pressure (RVSP) elevation. The mice that received Sugen 5416 pre-injection showed severe $\mathrm{PH}$ when combined with OVA stimulation (88). Moreover, hypoxia combined with OVAinduced mice PH development (32). These observations indicate the contribution of IgE in $\mathrm{PAH} / \mathrm{PH}$ development. IgE production occurs when B cells interact with Th2 cells $(33,35)$. As Th2 cells and Th2 response present in clinic PAH and experimental $\mathrm{PH}(31,32)$, these facilitate B-cell class-switching into $\operatorname{IgE}$ isotype. Indeed, in the Th2 activation model, IgE elevated in bronchoalveolar lavage fluid (BALF) of PH subjects (32). Mast cells are one of the effector cell types of $\operatorname{IgE}$, as it expresses the IgE high-affinity receptor FceRI. FceRI binds with IgE Fc fragment through its subunit (72). In clinic PAH and experimental $\mathrm{PH}$, mast cells infiltrate and locate around pulmonary vessels $(6,89,90)$. Mast cells inhibition prevents $\mathrm{PH}$ development in MCT-induced rats (11). Upon IgE stimulation, mast cells release vascular endothelial growth factors, IL-6, IL13, and IL-33 (91). These growth factors and cytokines have been reported to contribute to perivascular inflammation and vascular remodeling (92-95). These results strongly suggest the association of IgE in PAH/PH development. Omalizumab is an IgE antagonist (96). Omalizumab is used in treating asthma through blocking IgE (96). Blocking IgE through Omalizumab attenuated left heart failure and abdominal aortic aneurysm (85). Therefore, Omalizumab therapy is a promising strategy in $\mathrm{PAH} / \mathrm{PH}$ treatment once the contribution of IgE is demonstrated.

\section{IgA Isotype}

Immunoglobulin A is the second most abundant isotype in serum immunoglobulins, but the most frequent subtype at the mucosal site (97). IgA that is enriched in the respiratory system and intestinal tract is named mucosal IgA, as it participates in hostpathogen defense in the mucosal lumen. Mucosal IgA is dimeric IgA (linked by J chain) while circulating serum IgA is monomeric (98). Serum IgA elevation is reported in severe PH associated with primary Sjögren's syndrome (73), and IgA-producing plasma cells are found in the blood of patients with IPAH (51). IgA Fc receptor Fc $\alpha$ RI (CD89) is expressed by neutrophils. IgA activated neutrophils release leukotriene B4 (LTB4), which attract more neutrophils infiltration (74). Neutrophils infiltration and activation are observed in clinic PAH and experimental
$\mathrm{PH}$. The activated neutrophils released neutrophil extracellular traps (NETs), containing elastase, cytokines, chemokines, and proteases (7). These contents cause tissue damage and vascular disorder, such as ET1 release in PAECs and proliferation in PASMCs $(7,99)$. These results showed that IgA might induce neutrophil infiltration and activation in lung tissues of $\mathrm{PAH} / \mathrm{PH}$ subject through $\mathrm{Fc}$ receptor $\mathrm{Fc} \alpha \mathrm{RI}$, subsequently induce tissue damage. Moreover, dimeric IgA also has a J chain structure (81). Therefore, whether pIgR participates in IgA mediated vascular dysfunction will be determined by the structure of IgA (dimeric or monomeric structure). Several strategies have been designed to block IgA and Fc $\alpha$ RI to alleviate autoimmune injury. MIP8a, the anti-Fc $\alpha$ RI mAb, reduced neutrophils activation, NETs formation, and tissue damage in rheumatoid arthritis (RA) patients $(100,101)$. Also, the peptides that mimic IgA or Fc $\alpha$ RI sequences block the binding between IgA and FcoRI, decrease the infiltration of neutrophils induced by IgA (102).

\section{DISCUSSION}

Growing evidence indicates that adaptive response occurred in the lung tissues leads to local immunoglobulin production. These results support the observation that IPAH patients without autoimmune diseases also showed positive in auto-antibodies. The injury of auto-antibodies focuses on (a) vascular damage caused by antigen-antibody binding through Fab fragment; (b) leukocytes attraction and activation by Fc receptor. Moreover, the presence of TLOs and Th subtypes strongly suggested the B-cell activation and the diversity of immunoglobulin isotypes. IgE and IgA auto-antibodies might also exist besides IgG and IgM. Macrophages, mast cells, and neutrophils are known as participations in non-specific immunity. These innate immune cells are attracted by chemokines and activated by non-specific pathogens. Whether auto-antibodies are another attractors and activators for these effector cells warrant further investigation.

Based on clinical observation and experimental animal models, the production of auto-antibodies is both the cause and the consequence of IPAH development. Auto-antigens in pulmonary vessels should be phagocytized by APCs, which is the prerequisite in initiating the antibodies production. However, some experimental evidence is missing in this process: (a) if cell injury and cell death are needed in phagocytosis by APCs; (b) if antigen-presenting is stronger in mutation carriers. BMPR2 mutation promotes a pro-inflammatory and pro-apoptosis state in the endothelial cells (103). Whether endothelial cell apoptosis caused by BMPR2 mutation triggered APCs phagocytosis needs further investigation. The present studies demonstrated that AECAs promote adhesion and inflammation (64), other than the proliferation (66) in normal endothelial cells. Whether AECAs cause more severe vascular dysfunction in mutation carriers are unknown. Considering the incomplete penetrance in BMPR2 mutation, we hypothesize auto-immunity acts as an additional trigger that participates in disease progression in unaffected mutation carriers.

Remarkably, the auto-antibodies identified in patients with IPAH showed some similarities and differences with those 
in $\mathrm{PAH}$ with connective tissue diseases (PAH-CTD). Antigen targets are the most obvious differences. For the patients with IPAH, the antigen targets are exposed in pulmonary vessels, such as Lamin A/C in endothelial cells (Table 2), however, the targets in PAH-CTD are commonly nuclear (identified as antinuclear antibodies) or DNA (identified as anti-double-stranded DNA antibodies) (104). Then, the inner relationship between auto-antibodies and PAH is different. In PAH-CTD, autoantibodies heavily deposit in the connective tissues prior to the lung. $\mathrm{PH}$ is secondary to connective tissue diseases. However, for the patients with IPAH, auto-antibodies impaired pulmonary vessels first, while other tissues impairment is less reported. What is in common is that, autoantibodies reported in two kinds of $\mathrm{PAH}$ aggravate pulmonary vascular dysfunction. AECAs purified from IPAH and PAH-CTD show pro-inflammatory and proadhesive effects in endothelial cells, however, only AECAs from PAH-CTD promote proliferation in endothelial cells $(64,66)$. AFAs purified from the patients with SSC induced fibroblast activation (58). Auto-antibodies targeting the smooth muscle cells induced the contraction of cells (60). Auto-antibodies found in the experimental $\mathrm{PH}$ models activated complementary systems and aggravated inflammation in the PH lung (61).

Anti-inflammatory therapy has been evaluated for years. IL-6 is one of the most promising targets in treating the PAH (9). A pre-clinical study showed blocking IL-6 is effective in attenuating $\mathrm{PH}$ development in MCT rats, SuHx rats, and hypoxic mice $(9,95,105)$; however, the clinical trials of Tocilizumab (an IL-6 receptor antagonist) is less effective than expected (106). Other targets are also considered, such as TNF $\alpha$ (etanercept) and IL1 (anakinra). Of note, the anti-inflammatory drugs are feeble

\section{REFERENCES}

1. Rabinovitch M, Guignabert C, Humbert M, Nicolls MR. Inflammation and immunity in the pathogenesis of pulmonary arterial hypertension. Circ Res. (2014) 115:165-75. doi: 10.1161/CIRCRESAHA.113.301141

2. Li C, Liu P, Song R, Zhang Y, Lei S, Wu S. Immune cells and autoantibodies in pulmonary arterial hypertension. Acta Biochim Biophys Sin (Shanghai). (2017) 49:1047-57. doi: 10.1093/abbs/gmx095

3. Savai R, Pullamsetti SS, Kolbe J, Bieniek E, Voswinckel R, Fink L, et al. Immune and inflammatory cell involvement in the pathology of idiopathic pulmonary arterial hypertension. Am J Respir Crit Care Med. (2012) 186:897-908. doi: 10.1164/rccm.201202-0335OC

4. Humbert M, Guignabert C, Bonnet S, Dorfmuller P, Klinger JR, Nicolls $\mathrm{MR}$, et al. Pathology and pathobiology of pulmonary hypertension: state of the art and research perspectives. Eur Respir J. (2019) 53. doi: 10.1183/13993003.01887-2018

5. Zawia A, Arnold ND, West L, Pickworth JA, Turton H, Iremonger $\mathrm{J}$, et al. Altered Macrophage Polarization Induces Experimental Pulmonary Hypertension and Is Observed in Patients With Pulmonary Arterial Hypertension. Arterioscler Thromb Vasc Biol. (2021) 41:430-45. doi: 10.1161/ATVBAHA.120.314639

6. Farha S, Sharp J, Asosingh K, Park M, Comhair SA, Tang WH, et al. Mast cell number, phenotype, and function in human pulmonary arterial hypertension. Pulm Circ. (2012) 2:220-8. doi: 10.4103/2045-8932.97609

7. Taylor S, Dirir O, Zamanian RT, Rabinovitch M, Thompson AAR. The role of neutrophils and neutrophil elastase in pulmonary arterial hypertension. Front Med (Lausanne). (2018) 5:217. doi: 10.3389/fmed.2018.00217

8. Hurst LA, Dunmore BJ, Long L, Crosby A, Al-Lamki R, Deighton J, et al. TNFalpha drives pulmonary arterial hypertension by suppressing the BMP in suppressing the production of the immunoglobulin $(4,14)$, therefore, the other strategy should be taken to decrease the vascular injury caused by auto-antibodies. For IgE and $\operatorname{IgA}$, which are less important in maintaining host-defense, targeting the immunoglobulins themselves (such as Omalizumab and targeting IgE) or their Fc receptors (such as anti-Fc $\alpha$ RI mAb and targeting Fc receptor of IgA) might be effective in blocking autoimmune response. More directly, targeting B cells might limit the activation of B cells and slash the production of aberrant immunoglobulins. Rituximab is an anti-human CD20 type I chimeric antibody. Blocking CD20 by rituximab inhibits the proliferation of stimulated B cells. Rituximab is used to treat certain autoimmune diseases through decreasing auto-antibody production. The clinical trial revealed rituximab improved 6MWD in patients with PAH-CTD (NCT01086540). Whether restricting $\mathrm{B}$ cells affects IPAH development and whether rituximab is listed as first-line treatment will be uncovered in the near future.

\section{AUTHOR CONTRIBUTIONS}

TS wrote the manuscript. YX revised the manuscript. JW conceived the framework. All authors contributed to the article and approved the submitted version.

\section{FUNDING}

This study was financially supported by the National Key R\&D Program of China (Grant no: 2019YFA0801703) and the National Natural Science Foundation of China (Grant no: 82090011).

type-II receptor and altering NOTCH signalling. Nat Commun. (2017) 8:14079. doi: 10.1038/ncomms14079

9. Pullamsetti SS, Seeger W, Savai R. Classical IL-6 signaling: a promising therapeutic target for pulmonary arterial hypertension. J Clin Invest. (2018) 128:1720-3. doi: 10.1172/JCI120415

10. Abid S, Marcos E, Parpaleix A, Amsellem V, Breau M, Houssaini $A$, et al. CCR2/CCR5-mediated macrophage-smooth muscle cell crosstalk in pulmonary hypertension. Eur Respir J. (2019) 54. doi: 10.1183/13993003.02308-2018

11. Bartelds B, van Loon RLE, Mohaupt S, Wijnberg H, Dickinson MG, Boersma B, et al. Mast cell inhibition improves pulmonary vascular remodeling in pulmonary hypertension. Chest. (2012) 141:651-60. doi: 10.1378/chest.11-0663

12. Larsen KO, Yndestad A, Sjaastad I, Loberg EM, Goverud IL, Halvorsen $B$, et al. Lack of CCR7 induces pulmonary hypertension involving perivascular leukocyte infiltration and inflammation. Am J Physiol Lung Cell Mol Physiol. (2011) 301:L50-59. doi: 10.1152/ajplung.00048. 2010

13. van Uden D, Boomars K, Kool M. Dendritic cell subsets and effector function in idiopathic and connective tissue disease-associated pulmonary arterial hypertension. Front Immunol. (2019) 10:11. doi: 10.3389/fimmu.2019. 00011

14. Arends SJ, Damoiseaux J, Duijvestijn A, Debrus-Palmans L, Boomars K, Broers B, et al. Prevalence of anti-endothelial cell antibodies in idiopathic pulmonary arterial hypertension. Eur Respir J. (2010) 35:9235. doi: 10.1183/09031936.00164209

15. Price LC, Wort SJ, Perros F, Dorfmuller P, Huertas A, Montani D, et al. Inflammation in pulmonary arterial hypertension. Chest. (2012) 141:21021. doi: $10.1378 /$ chest.11-0793 
16. Nicolls MR, Taraseviciene-Stewart L, Rai PR, Badesch DB, Voelkel NF. Autoimmunity and pulmonary hypertension: a perspective. Eur Respir J. (2005) 26:1110-8. doi: 10.1183/09031936.05.00045705

17. Perros F, Dorfmuller P, Souza R, Durand-Gasselin I, Mussot S, Mazmanian M, et al. Dendritic cell recruitment in lesions of human and experimental pulmonary hypertension. Eur Respir J. (2007) 29:462-8. doi: 10.1183/09031936.00094706

18. Balan S, Saxena M, Bhardwaj N. Dendritic cell subsets and locations. Int Rev Cell Mol Biol. (2019) 348:1-68. doi: 10.1016/bs.ircmb.2019.07.004

19. Bachem A, Guttler S, Hartung E, Ebstein F, Schaefer M, Tannert A, et al. Superior antigen cross-presentation and XCR1 expression define human CD11c+CD141+ cells as homologues of mouse CD $8+$ dendritic cells. J Exp Med. (2010) 207:1273-81. doi: 10.1084/jem.20100348

20. Wang W, Yan H, Zhu W, Cui Y, Chen J, Wang X, et al. Impairment of monocyte-derived dendritic cells in idiopathic pulmonary arterial hypertension. J Clin Immunol. (2009) 29:705-13. doi: 10.1007/s10875-009-9322-8

21. Marsh LM, Jandl K, Grunig G, Foris V, Bashir M, Ghanim B, et al. The inflammatory cell landscape in the lungs of patients with idiopathic pulmonary arterial hypertension. Eur Respir J. (2018) 51. doi: 10.1183/13993003.01214-2017

22. Ivanov S, Scallan JP, Kim KW, Werth K, Johnson MW, Saunders BT, et al. CCR7 and IRF4-dependent dendritic cells regulate lymphatic collecting vessel permeability. J Clin Invest. (2016) 126:1581-91. doi: 10.1172/JCI84518

23. Clarkson BD, Walker A, Harris MG, Rayasam A, Hsu M, Sandor M, et al. CCR7 deficient inflammatory Dendritic Cells are retained in the Central Nervous System. Sci Rep. (2017) 7:42856. doi: 10.1038/srep42856

24. Koudstaal T, van Hulst JAC, Das T, Neys SFH, Merkus D, Bergen IM, et al. DNGR1-Cre-mediated Deletion of Tnfaip3/A20 in Conventional Dendritic Cells Induces Pulmonary Hypertension in Mice. Am J Respir Cell Mol Biol. (2020) 63:665-80. doi: 10.1165/rcmb.2019-0443OC

25. Reizis B. Plasmacytoid Dendritic Cells: Development, Regulation, and Function. Immunity. (2019) 50:37-50. doi: 10.1016/j.immuni.2018.12.027

26. Cerutti A, Qiao X, He B. Plasmacytoid dendritic cells and the regulation of immunoglobulin heavy chain class switching. Immunol Cell Biol. (2005) 83:554-62. doi: 10.1111/j.1440-1711.2005.01389.x

27. Collin M, McGovern N, Haniffa M. Human dendritic cell subsets. Immunology. (2013) 140:22-30. doi: 10.1111/imm.12117

28. Luckheeram RV, Zhou R, Verma AD, Xia B. CD4(+)T cells: differentiation and functions. Clin Dev Immunol. (2012) 2012:925135. doi: 10.1155/2012/925135

29. Kumar S, Jeong Y, Ashraf MU, Bae YS. Dendritic cell-mediated Th2 immunity and immune disorders. Int J Mol Sci. (2019) 20:2159. doi: 10.3390/ijms20092159

30. Zhu J, Yamane H, Cote-Sierra J, Guo L, Paul WE. GATA-3 promotes Th2 responses through three different mechanisms: induction of Th2 cytokine production, selective growth of Th2 cells and inhibition of Th1 cell-specific factors. Cell Res. (2006) 16:3-10. doi: 10.1038/sj.cr.7310002

31. Daley E, Emson C, Guignabert C, de Waal Malefyt R, Louten J, Kurup VP, et al. Pulmonary arterial remodeling induced by a Th2 immune response. J Exp Med. (2008) 205:361-72. doi: 10.1084/jem.20071008

32. Chen G, Zuo S, Tang J, Zuo C, Jia D, Liu Q, et al. Inhibition of CRTH2mediated Th2 activation attenuates pulmonary hypertension in mice. J Exp Med. (2018) 215:2175-95. doi: 10.1084/jem.20171767

33. Lebman DA, Coffman RL. Interleukin 4 causes isotype switching to IgE in T cell-stimulated clonal B cell cultures. J Exp Med. (1988) 168:85362. doi: 10.1084 /jem.168.3.853

34. Cerutti A. The regulation of IgA class switching. Nat Rev Immunol. (2008) 8:421-34. doi: 10.1038/nri2322

35. Kashiwada M, Levy DM, McKeag L, Murray K, Schroder AJ, Canfield SM, et al. IL-4-induced transcription factor NFIL3/E4BP4 controls IgE class switching. Proc Natl Acad Sci USA. (2010) 107:821-6. doi: 10.1073/pnas.0909235107

36. Maston LD, Jones DT, Giermakowska W, Howard TA, Cannon JL, Wang $\mathrm{W}$, et al. Central role of $\mathrm{T}$ helper 17 cells in chronic hypoxia-induced pulmonary hypertension. Am J Physiol Lung Cell Mol Physiol. (2017) 312:L609-24. doi: 10.1152/ajplung.00531.2016
37. Wang L, Liu J, Wang W, Qi X, Wang Y, Tian B, et al. Targeting IL-17 attenuates hypoxia-induced pulmonary hypertension through downregulation of beta-catenin. Thorax. (2019) 74:564-78. doi: 10.1136/thoraxjnl-2018-211846

38. Korn T, Muschaweckh A. Stability and maintenance of foxp3(+) treg cells in non-lymphoid microenvironments. Front Immunol. (2019) 10:2634. doi: 10.3389/fimmu.2019.02634

39. Miyata M, Sakuma F, Ito M, Ohira H, Sato Y, Kasukawa R. Athymic nude rats develop severe pulmonary hypertension following monocrotaline administration. Int Arch Allergy Immunol. (2000) 121:246-52. doi: 10.1159/000024324

40. Tamosiuniene R, Tian W, Dhillon G, Wang L, Sung YK, Gera L, et al. Regulatory $\mathrm{T}$ cells limit vascular endothelial injury and prevent pulmonary hypertension. Circ Res. (2011) 109:867-79. doi: 10.1161/CIRCRESAHA.110.236927

41. Tamosiuniene R, Manouvakhova O, Mesange P, Saito T, Qian J, Sanyal M, et al. Dominant Role for Regulatory $\mathrm{T}$ Cells in Protecting Females Against Pulmonary Hypertension. Circ Res. (2018) 122:1689702. doi: 10.1161/CIRCRESAHA.117.312058

42. Chu Y, Xiangli X, Xiao W. Regulatory T cells protect against hypoxiainduced pulmonary arterial hypertension in mice. Mol Med Rep. (2015) 11:3181-7. doi: 10.3892/mmr.2014.3106

43. Austin ED, Rock MT, Mosse CA, Vnencak-Jones CL, Yoder SM, Robbins IM, et al. T lymphocyte subset abnormalities in the blood and lung in pulmonary arterial hypertension. Respir Med. (2010) 104:45462. doi: 10.1016/j.rmed.2009.10.004

44. Tamosiuniene R, Nicolls MR. Regulatory $T$ cells and pulmonary hypertension. Trends Cardiovasc Med. (2011) 21:166-71. doi: 10.1016/j.tcm.2012.05.004

45. Sada Y, Dohi Y, Uga S, Higashi A, Kinoshita H, Kihara Y. Non-suppressive regulatory $\mathrm{T}$ cell subset expansion in pulmonary arterial hypertension. Heart Vessels. (2016) 31:1319-26. doi: 10.1007/s00380-015-0727-4

46. Ulrich S, Nicolls MR, Taraseviciene L, Speich R, Voelkel N. Increased regulatory and decreased CD8+ cytotoxic T cells in the blood of patients with idiopathic pulmonary arterial hypertension. Respiration. (2008) 75:27280. doi: $10.1159 / 000111548$

47. Ars C, Thurion P, Delos M, Sibille Y, Pilette C. Small airway obstruction in severe pulmonary arterial hypertension correlates with increased airway CD8+ T-cells and fractalkine expression. Eur Respir J. (2009) 34:14946. doi: 10.1183/09031936.00140109

48. Fay NS, Larson EC, Jameson JM. Chronic Inflammation and gammadelta T Cells. Front Immunol. (2016) 7:210. doi: 10.3389/fimmu.2016.00210

49. Colvin KL, Cripe PJ, Ivy DD, Stenmark KR, Yeager ME. Bronchusassociated lymphoid tissue in pulmonary hypertension produces pathologic autoantibodies. Am J Respir Crit Care Med. (2013) 188:1126-36. doi: 10.1164/rccm.201302-0403OC

50. Breitling S, Hui Z, Zabini D, Hu Y, Hoffmann J, Goldenberg NM, et al. The mast cell-B cell axis in lung vascular remodeling and pulmonary hypertension. Am J Physiol Lung Cell Mol Physiol. (2017) 312:L71021. doi: 10.1152/ajplung.00311.2016

51. Blum LK, Cao RRL, Sweatt AJ, Bill M, Lahey LJ, Hsi AC, et al. Circulating plasmablasts are elevated and produce pathogenic anti-endothelial cell autoantibodies in idiopathic pulmonary arterial hypertension. Eur J Immunol. (2018) 48:874-84. doi: 10.1002/eji.201747460

52. Perros F, Dorfmuller P, Montani D, Hammad H, Waelput W, Girerd $\mathrm{B}$, et al. Pulmonary lymphoid neogenesis in idiopathic pulmonary arterial hypertension. Am J Respir Crit Care Med. (2012) 185:31121. doi: 10.1164/rccm.201105-0927OC

53. Yu K, Lieber MR. Current insights into the mechanism of mammalian immunoglobulin class switch recombination. Crit Rev Biochem Mol Biol. (2019) 54:333-51. doi: 10.1080/10409238.2019.165 9227

54. Gascan H, Gauchat JF, Aversa G, Van Vlasselaer P, de Vries JE. Anti-CD40 monoclonal antibodies or CD4+ T cell clones and IL-4 induce IgG4 and IgE switching in purified human B cells via different signaling pathways. J Immunol. (1991) 147:8-13. doi: 10.1093/intimm/4. 3.397 
55. Heukels $\mathrm{P}$, Corneth OBJ, van Uden D, van Hulst JAC, van den Toorn LM, van den Bosch AE, et al. Loss of immune homeostasis in patients with idiopathic pulmonary arterial hypertension. Thorax. (2021) doi: 10.1136/thoraxjnl-2020-215460. [Epub ahead of print].

56. Mohanta SK, Yin C, Peng L, Srikakulapu P, Bontha V, Hu D, et al. Artery tertiary lymphoid organs contribute to innate and adaptive immune responses in advanced mouse atherosclerosis. Circ Res. (2014) 114:177287. doi: 10.1161/CIRCRESAHA.114.301137

57. Srikakulapu P, Hu D, Yin C, Mohanta SK, Bontha SV, Peng L, et al. Artery tertiary lymphoid organs control multilayered territorialized atherosclerosis B-cell responses in aged ApoE-/- mice. Arterioscler Thromb Vasc Biol. (2016) 36:1174-85. doi: 10.1161/ATVBAHA.115.306983

58. Terrier B, Tamby MC, Camoin L, Guilpain P, Broussard C, Bussone $\mathrm{G}$, et al. Identification of target antigens of antifibroblast antibodies in pulmonary arterial hypertension. Am J Respir Crit Care Med. (2008) 177:1128-34. doi: 10.1164/rccm.200707-1015OC

59. Dib H, Tamby MC, Bussone G, Regent A, Berezne A, Lafine C, et al. Targets of anti-endothelial cell antibodies in pulmonary hypertension and scleroderma. Eur Respir J. (2012) 39:1405-14. doi: 10.1183/09031936.00181410

60. Bussone G, Tamby MC, Calzas C, Kherbeck N, Sahbatou Y, Sanson C, et al. IgG from patients with pulmonary arterial hypertension and/or systemic sclerosis binds to vascular smooth muscle cells and induces cell contraction. Ann Rheum Dis. (2012) 71:596-605. doi: 10.1136/annrheumdis-2011-200195

61. Frid MG, McKeon BA, Thurman JM, Maron BA, Li M, Zhang $\mathrm{H}$, et al. Immunoglobulin-driven Complement Activation Regulates Proinflammatory Remodeling in Pulmonary Hypertension. Am J Respir Crit Care Med. (2020) 201:224-39. doi: 10.1164/rccm.201903-0591OC

62. Tamby MC, Chanseaud Y, Humbert M, Fermanian J, Guilpain P, Garciade-la-Pena-Lefebvre $\mathrm{P}$, et al. Anti-endothelial cell antibodies in idiopathic and systemic sclerosis associated pulmonary arterial hypertension. Thorax. (2005) 60:765-72. doi: 10.1136/thx.2004.029082

63. Fineschi S, Goffin L, Rezzonico R, Cozzi F, Dayer JM, Meroni PL, et al. Antifibroblast antibodies in systemic sclerosis induce fibroblasts to produce profibrotic chemokines, with partial exploitation of toll-like receptor 4 . Arthritis Rheum. (2008) 58:3913-23. doi: 10.1002/art.24049

64. Arends SJ, Damoiseaux JG, Duijvestijn AM, Debrus-Palmans L, Boomars KA, Brunner-La Rocca HP, et al. Functional implications of IgG anti-endothelial cell antibodies in pulmonary arterial hypertension. Autoimmunity. (2013) 46:463-70. doi: 10.3109/08916934.2013.812080

65. Pfau JC, Li S, Holland S, Sentissi JJ. Alteration of fibroblast phenotype by asbestos-induced autoantibodies. J Immunotoxicol. (2011) 8:15969. doi: 10.3109/1547691X.2011.562257

66. Arends SJ, Damoiseaux JG, Duijvestijn AM, Debrus-Palmans L, Vroomen M, Boomars KA, et al. Immunoglobulin G anti-endothelial cell antibodies: inducers of endothelial cell apoptosis in pulmonary arterial hypertension? Clin Exp Immunol. (2013) 174:433-40. doi: 10.1111/cei.12166

67. Pincetic A, Bournazos S, DiLillo DJ, Maamary J, Wang TT, Dahan R, et al. Type I and type II Fc receptors regulate innate and adaptive immunity. Nat Immunol. (2014) 15:707-16. doi: 10.1038/ni.2939

68. Tanigaki K, Sundgren N, Khera A, Vongpatanasin W, Mineo C, Shaul PW. Fcgamma receptors and ligands and cardiovascular disease. Circ Res. (2015) 116:368-84. doi: 10.1161/CIRCRESAHA.116.302795

69. Nguyen TT, Klasener K, Zurn C, Castillo PA, Brust-Mascher I, Imai DM, et al. The IgM receptor FcmuR limits tonic BCR signaling by regulating expression of the IgM BCR. Nat Immunol. (2017) 18:321-33. doi: 10.1038/ni.3677

70. Meryk A, Pangrazzi L, Hagen M, Hatzmann F, Jenewein B, Jakic B, et al. Fcmu receptor as a costimulatory molecule for T cells. Cell Rep. (2019) 26:2681-91 e2685. doi: 10.1016/j.celrep.2019.02.024

71. Kubagawa H, Honjo K, Ohkura N, Sakaguchi S, Radbruch A, Melchers F, et al. Functional roles of the IgM Fc receptor in the immune system. Front Immunol. (2019) 10:945. doi: 10.3389/fimmu.2019.00945

72. Wu LC, Zarrin AA. The production and regulation of IgE by the immune system. Nat Rev Immunol. (2014) 14:247-59. doi: 10.1038/nri3632

73. Nakagawa N, Osanai S, Ide H, Nishigaki Y, Takahashi S, Nakano H, et al. Severe pulmonary hypertension associated with primary Sjogren's syndrome. Intern Med. (2003) 42:1248-52. doi: 10.2169/internalmedicine.42.1248

74. Steffen U, Koeleman CA, Sokolova MV, Bang H, Kleyer A, Rech J, et al. IgA subclasses have different effector functions associated with distinct glycosylation profiles. Nat Commun. (2020) 11:120. doi: 10.1038/s41467-019-13992-8

75. Jia D, Bai P, Wan N, Liu J, Zhu Q, He Y, et al. Niacin Attenuates Pulmonary Hypertension Through H-PGDS in Macrophages. Circ Res. (2020) 127:132336. doi: 10.1161/CIRCRESAHA.120.316784

76. Anderson CF, Gerber JS, Mosser DM. Modulating macrophage function with IgG immune complexes. J Endotoxin Res. (2002) 8:477-81. doi: 10.1177/09680519020080060501

77. Banki Z, Werner R, Riepler L, Rossler A, Mullauer B, Hegen V, et al. Fcgamma receptor type I (CD64)-mediated impairment of the capacity of dendritic cells to activate specific CD8 T cells by IgGopsonized friend virus. Viruses. (2019) 11:145. doi: 10.3390/v11020 145

78. Gadjeva MG, Rouseva MM, Zlatarova AS, Reid KB, Kishore U, Kojouharova MS. Interaction of human $\mathrm{Clq}$ with IgG and IgM: revisited. Biochemistry. (2008) 47:13093-102. doi: 10.1021/bi801131h

79. Bauer EM, Zheng H, Comhair S, Erzurum S, Billiar TR, Bauer PM. Complement C3 deficiency attenuates chronic hypoxiainduced pulmonary hypertension in mice. PLoS ONE. (2011) 6:e28578. doi: 10.1371/journal.pone.0028578

80. Frid MG, Thurman JM, Hansen KC, Maron BA, Stenmark KR. Inflammation, immunity, and vascular remodeling in pulmonary hypertension; Evidence for complement involvement? Glob Cardiol Sci Pract. (2020) 2020:e202001. doi: 10.21542/gcsp.2020.1

81. Ocak S, Pedchenko TV, Chen H, Harris FT, Qian J, Polosukhin $\mathrm{V}$, et al. Loss of polymeric immunoglobulin receptor expression is associated with lung tumourigenesis. Eur Respir J. (2012) 39:117180. doi: 10.1183/09031936.00184410

82. Cao AT, Yao S, Gong B, Elson CO, Cong Y. Th17 cells upregulate polymeric Ig receptor and intestinal IgA and contribute to intestinal homeostasis. J Immunol. (2012) 189:4666-73. doi: 10.4049/jimmunol.1200 955

83. Kumar P, Monin L, Castillo P, Elsegeiny W, Horne W, Eddens T, et al. Intestinal interleukin-17 receptor signaling mediates reciprocal control of the gut microbiota and autoimmune inflammation. Immunity. (2016) 44:65971. doi: 10.1016/j.immuni.2016.02.007

84. Gould HJ, Sutton BJ. IgE in allergy and asthma today. Nat Rev Immunol. (2008) 8:205-17. doi: 10.1038/nri2273

85. Wang J, Lindholt JS, Sukhova GK, Shi MA, Xia M, Chen H, et al. IgE actions on CD4+ T cells, mast cells, and macrophages participate in the pathogenesis of experimental abdominal aortic aneurysms. EMBO Mol Med. (2014) 6:952-69. doi: 10.15252/emmm.201303811

86. Guo W, Gao R, Zhang W, Ge W, Ren M, Li B, et al. IgE aggravates the senescence of smooth muscle cells in abdominal aortic aneurysm by upregulating LincRNA-p21. Aging Dis. (2019) 10:699-710. doi: 10.14336/AD.2018.1128

87. Zhang X, Li J, Luo S, Wang M, Huang Q, Deng Z, et al. IgE contributes to atherosclerosis and obesity by affecting macrophage polarization, macrophage protein network, and foam cell formation. Arterioscler Thromb Vasc Biol. (2020) 40:597-610. doi: 10.1161/ATVBAHA.119.31 3744

88. Mizuno S, Farkas L, Al Husseini A, Farkas D, Gomez-Arroyo J, Kraskauskas D, et al. Severe pulmonary arterial hypertension induced by SU5416 and ovalbumin immunization. Am J Respir Cell Mol Biol. (2012) 47:67987. doi: 10.1165/rcmb.2012-0077OC

89. Montani D, Perros F, Gambaryan N, Girerd B, Dorfmuller P, Price LC, et al. C-kit-positive cells accumulate in remodeled vessels of idiopathic pulmonary arterial hypertension. Am J Respir Crit Care Med. (2011) 184:116-23. doi: 10.1164/rccm.201006-0905OC

90. Dahlin JS, Hallgren J. Mast cell progenitors: origin, development and migration to tissues. Mol Immunol. (2015) 63:917. doi: 10.1016/j.molimm.2014.01.018

91. Sibilano R, Frossi B, Pucillo CE. Mast cell activation: a complex interplay of positive and negative signaling pathways. Eur J Immunol. (2014) 44:255866. doi: 10.1002/eji.201444546

92. Schermuly RT, Ghofrani HA, Wilkins MR, Grimminger F. Mechanisms of disease: pulmonary arterial hypertension. Nat Rev Cardiol. (2011) 8:44355. doi: 10.1038/nrcardio. 2011.87 
93. Liu J, Wang W, Wang L, Chen S, Tian B, Huang K, et al. IL-33 Initiates Vascular Remodelling in Hypoxic Pulmonary Hypertension by upRegulating HIF-1alpha and VEGF Expression in Vascular Endothelial Cells. EBioMedicine. (2018) 33:196-210. doi: 10.1016/j.ebiom.2018.06.003

94. Takagi K, Yamakuchi M, Matsuyama T, Kondo K, Uchida A, Misono S, et al. IL-13 enhances mesenchymal transition of pulmonary artery endothelial cells via down-regulation of miR-424/503 in vitro. Cell Signal. (2018) 42:27080. doi: 10.1016/j.cellsig.2017.10.019

95. Simpson CE, Chen JY, Damico RL, Hassoun PM, Martin LJ, Yang J, et al. Cellular sources of interleukin- 6 and associations with clinical phenotypes and outcomes in pulmonary arterial hypertension. Eur Respir J. (2020) 55:1901761. doi: 10.1183/13993003.01761-2019

96. Chung KF. Anti-IgE monoclonal antibody, omalizumab: a new treatment for allergic asthma. Expert Opin Pharmacother. (2004) 5:439-46. doi: 10.1517/14656566.5.2.439

97. Breedveld A, van Egmond M. IgA and FcalphaRI: pathological roles and therapeutic opportunities. Front Immunol. (2019) 10:553. doi: 10.3389/fimmu.2019.00553

98. van Gool MMJ, van Egmond M. IgA and FcalphaRI: versatile players in homeostasis, infection, and autoimmunity. Immunotargets Ther. (2020) 9:351-72. doi: 10.2147/ITT.S266242

99. Aldabbous L, Abdul-Salam V, McKinnon T, Duluc L, Pepke-Zaba J, Southwood M, et al. neutrophil extracellular traps promote angiogenesis: evidence from vascular pathology in pulmonary hypertension. Arterioscler Thromb Vasc Biol. (2016) 36:2078-87. doi: 10.1161/ATVBAHA.116.30 7634

100. Zhang W, Bi B, Oldroyd RG, Lachmann PJ. Neutrophil lactoferrin release induced by IgA immune complexes differed from that induced by cross-linking of fcalpha receptors (FcalphaR) with a monoclonal antibody, MIP8a. Clin Exp Immunol. (2000) 121:106-11. doi: 10.1046/j.1365-2249.2000.01254.x

101. Liu C, Kanamaru Y, Watanabe T, Tada N, Horikoshi S, Suzuki Y, et al. Targeted IgA Fc receptor I (FcalphaRI) therapy in the early intervention and treatment of pristane-induced lupus nephritis in mice. Clin Exp Immunol. (2015) 181:407-16. doi: 10.1111/cei.12647

102. Heineke MH, van der Steen LPE, Korthouwer RM, Hage JJ, Langedijk JPM, Benschop JJ, et al. Peptide mimetics of immunoglobulin A (IgA) and
FcalphaRI block IgA-induced human neutrophil activation and migration. Eur J Immunol. (2017) 47:1835-45. doi: 10.1002/eji.201646782

103. Diebold I, Hennigs JK, Miyagawa K, Li CG, Nickel NP, Kaschwich M, et al. BMPR2 preserves mitochondrial function and DNA during reoxygenation to promote endothelial cell survival and reverse pulmonary hypertension. Cell Metab. (2015) 21:596-608. doi: 10.1016/j.cmet.2015.03.010

104. Nunes JPL, Cunha AC, Meirinhos T, Nunes A, Araujo PM, Godinho $\mathrm{AR}$, et al. Prevalence of auto-antibodies associated to pulmonary arterial hypertension in scleroderma-A review. Autoimmun Rev. (2018) 17:1186201. doi: 10.1016/j.autrev.2018.06.009

105. Steiner MK, Syrkina OL, Kolliputi N, Mark EJ, Hales CA, Waxman AB. Interleukin-6 overexpression induces pulmonary hypertension. Circ Res. (2009) 104:236-244 28 following 244. doi: 10.1161/CIRCRESAHA.108.182014

106. Hernandez-Sanchez J, Harlow L, Church C, Gaine S, Knightbridge E, Bunclark $\mathrm{K}$, et al. Clinical trial protocol for TRANSFORMUK: a therapeutic open-label study of tocilizumab in the treatment of pulmonary arterial hypertension. Pulm Circ. (2018) 8:2045893217735820. doi: 10.1177/2045893217735820

Conflict of Interest: The authors declare that the research was conducted in the absence of any commercial or financial relationships that could be construed as a potential conflict of interest.

Publisher's Note: All claims expressed in this article are solely those of the authors and do not necessarily represent those of their affiliated organizations, or those of the publisher, the editors and the reviewers. Any product that may be evaluated in this article, or claim that may be made by its manufacturer, is not guaranteed or endorsed by the publisher.

Copyright (c) 2021 Shu, Xing and Wang. This is an open-access article distributed under the terms of the Creative Commons Attribution License (CC BY). The use, distribution or reproduction in other forums is permitted, provided the original author(s) and the copyright owner(s) are credited and that the original publication in this journal is cited, in accordance with accepted academic practice. No use, distribution or reproduction is permitted which does not comply with these terms. 